Natural baking starter made from common ingredients such as flour, water and sugar is considered healthy. Any starter obtained by spontaneous fermentation is always a symbiosis of lactic acid bacteria and yeast. Lactic acid bacteria and yeast get along well together and in the course of their life enrich bread with the most valuable compounds, including shortchain organic acids, dietary fiber, essential amino acids, vitamins, etc. On the basis of the obtained research results, a recipe and technological modes for preparing dough for no yeast bakery products from wheat flour of the first grade with the use of ionozonized water, whey and natural starter have been developed. The dough was prepared in a safe way under pressure in a kneading-beating ion-ozone cavitation unit. The recipe components (raw materials) of the dough were loaded into the kneading body of the unit, then the dough was replaced for 5 minutes at a kneading body rotation frequency of $5 s^{-1}$ in different rotation modes and times. Then the ionozone treatment was carried out using an excess pressure of $0.40 \mathrm{MPa}$ (cavitation) and the dough was knocked down. The nutritional value, safety and shelf life of the developed no yeast bakery products with the addition of whey, starter and ionozonized water have been determined. It was found that in terms of organoleptic and physicochemical indicators, bread samples prepared from first grade wheat flour and ion-ozonized water without yeast and using whey are almost 2 times inferior to the quality of the control sample. As a result, it was found that churning for 3-5 minutes at a kneading body rotation frequency of $4-5 s^{-1}$ will be the optimal mode for obtaining a no yeast dough made from first grade flour on starter with the addition of whey and ionozonized water

Keywords: ion-ozonized water, no yeast bread, wheat flour, accelerated technology, natural culture

\section{DEVELOPMENT OF AN INNOVATIVE TECHNOLOGY FOR ACCELERATED COOKING OF NO YEAST BREAD USING ION-OZONIZED WATER}

\author{
A u yelbek I z tayev \\ Doctor of Technical Sciences, Professor, \\ Academician of the National Academy of Sciences \\ of the Republic of Kazakhstan, Director* \\ Mariam Alimardanova \\ Doctor of Technical Sciences, Professor \\ Department of Technology of Food Products $* * *$ \\ B a u y z han I z t a yev \\ $\mathrm{PhD}$, Leading Researcher* \\ Mira Yerzhanova \\ $\mathrm{PhD}$, Acting Associate Professor \\ Department of Automation and Telecommunications \\ M. Kh. Dulaty Taraz Regional University \\ Tole bi str., 40, Taraz, Republic of Kazakhstan, 080000 \\ UIbala Tungyshbayeva \\ $\mathrm{PhD}$, Lecturer** \\ Raushan Izteliyeva \\ $\mathrm{PhD}$, Senior Lecturer** \\ Sholpan Tursunbaeva \\ Corresponding Author \\ Lecturer \\ Department of Technology of Bread Products \\ and Processing Industries*** \\ E-mail: sh-tursunbaeva@mail.ru \\ * Science Research Institute for Food Technologies *** \\ ** Department of Food Safety and Quality*** \\ *** Almaty Technological University \\ Tole bi str., 100, Almaty, Republic of Kazakhstan, 050012
}

\section{Introduction}

In works [1-3] information is given that "no yeast" bread is prepared at enterprises using natural starter without adding compressed yeast to the recipe, and the loosening of the dough is provided by pure cultures of yeast cells from the previously withdrawn starter. Fermentation, which occurs due to the introduction of starter, makes noticeable changes in flour, which in turn makes bread more nutritious for the human body. The creation of a large number of specific types of fiber, food and nutrients means that the starter is a prebiotic. Prebiotics feed our beneficial bacteria in the gut, help them multiply, thrive, and support microbes essential to our health. In this regard, the development of a new technology for accelerated preparation of no yeast bread using natural baking starter, which contributes to an increase in the nutrients of no yeast bakery products, is relevant. 


\section{Literature review and problem statement}

The assortment of bakery products is increasing every year. At the same time, it is necessary to ensure their quality and safety. In work [4] it is shown that traditional bakery products do not differ in special useful properties, long shelf life, therefore, manufacturers are increasingly improving the formulation of their products. The solution to this problem of the quality and safety of bakery products depends not only on changes in the composition of ingredients and the balance of the nutrition structure, but also on the equipment that provides the required performance. At the same time, the creation of no yeast dough with an accelerated production cycle is relevant.

The work [5] presents the results of a study of methods of mechanical loosening of the dough. It is shown that by churning, no yeast dough is obtained in the following sequence: a part of the dough (in a liquid and cold state) is churned for 5 minutes in a special churning machine of strong and heavy construction. After a break, the knocked down mass is fed into an ordinary kneading machine, in which the dough is kneaded, which then goes to cutting and baking. But there were unresolved issues related to the fact that these methods do not improve the dough quality and have not found application in industry. The reason for this may be high energy costs, reduced labor productivity, etc. An option to overcome these difficulties may be to use the starter or other initiators, or preparation methods.

According to the source [6], manufacturers need to expand the range of no yeast bakery products through the development of new, original formulations of products of increased nutritional value, functional products using highly effective technologies to increase consumer demand. The popularity of proper nutrition has made no yeast bread one of the most common baked goods of choice for healthy eating enthusiasts. Therefore, the development of a new effective technology for the preparation of no yeast bakery products is necessary for production.

In the past 10 years, ozone technology has been increasingly used in the food industry, which has a number of advantages over special additives and technologies. In work [7] ozone technology is used to improve the safety and quality of food products. Also in work [8] results of determination of microbial and physicochemical changes during storage of wheat flour treated with ozone are given. But these technologies have not been used in the production of bakery products, so they have not been deeply studied.

Scientists are conducting research on the use of ozonized, ionized and ion-ozonized water in the production of flour, bakery, pasta, flour confectionery. As a result, the quality, safety and environmental friendliness of finished products are improved. In works $[9,10]$ it is shown that the use of agents of ion-ozone technology, which have many useful properties in food production, is the latest trend and is a promising direction in food production. The advantage of using an ion-ozone mixture for food processing allows, unlike other similar technologies, to process products without harmful impurities and radiation. At the same time, the ion-ozone cavitation technology of dough preparation, being simple and inexpensive, in which the dough rises, like with yeast, is environmentally friendly. This is due to the fact that ozone produces powerful disinfection, deodorization, excludes yeast additives, does not give harmful emissions into the biosphere and complies with the current environmental standards.

\section{The aim and objectives of research}

The aim of research is to develop an innovative ion-ozone cavitation technology of no yeast bread products in order to improve the quality, reduce the technological production process, increase labor productivity and increase the socio-economic indicators of bakery enterprises. This will make it possible to increase production efficiency, ensure the competitiveness of products, also increase sales, and, consequently, profits, etc.

To achieve the aim, the following objectives were set:

- to develop technologies for preparing no yeast bread from first grade wheat flour;

- to investigate the qualities of no yeast bread made from first grade wheat flour;

- to investigate the nutritional value and safety assessment of no yeast bread made from first grade wheat flour.

\section{Materials and methods of research}

The objects of research are wheat flour of the first grade, dry milk whey, natural starter, table salt "Araltuz", ion-ozonized water.

In the work, the following indicators of the raw materials used and the resulting bread were investigated: organoleptic indicators according to GOST 5667-85, mass fraction of moisture according to GOST 21094-75, mass fraction of fat according to GOST 5668-68. The mass fraction of protein is determined in accordance with GOST 1084691, the mass fraction of carbohydrates is determined in accordance with GOST 25832-89, the mass fraction of ash is determined in accordance with GOST 5901-2014 and the mass fraction of porosity is determined in accordance with GOST 5669-96. Also, the acidity content is determined according to GOST 5670-96, the number of mesophilic aerobic and facultative anaerobic microorganisms (KMAFanM) is determined according to GOST 10444.15-94, the number of bacteria of the E. coli group (coliform bacteria) (BGKP) is determined according to GOST 31747-2012. And the amount of osmotolerant yeasts and molds is determined according to GOST 28805-90.

To study the quality of no yeast bread from first grade wheat flour, bread was baked in laboratory conditions. Bread dough (control sample) was prepared in a safe way according to the recipe presented in Table 1 . Kneading the dough, fermentation, proofing and baking bread was carried out according to the methods described in the manual [11].

Table 1

Recipe for the preparation of a control sample of the dough by the straight dough methods

\begin{tabular}{|c|c|}
\hline $\begin{array}{c}\text { Name of raw materials } \\
\text { Grade } \\
\text { graur of the first }\end{array}$ & Raw material consumption \\
\hline Pressed yeast & 100 \\
\hline Table salt & 2.5 \\
\hline Water & 1.5 \\
\hline $\begin{array}{c}\text { (calculated based on flour moisture } \\
\text { content) }\end{array}$ \\
\hline
\end{tabular}

The obtained samples of no yeast bread products from wheat flour based on the ion-ozone cavitation technology of dough preparation were sent to an accredited testing laboratory. 
Articles [12-15] provide information on the ion-ozone cavitation plant, ion-ozone treatment of plant raw materials, and others.

Scientists of the Almaty Technological University have developed a laboratory ion-ozone cavitation unit for preparing no yeast dough, the diagram of which is shown in Fig. 1.

The dough is obtained by mechanical loosening under pressure. The ion-ozone cavitation unit for the preparation of dough with an accelerated cycle is intended for use in bakeries.

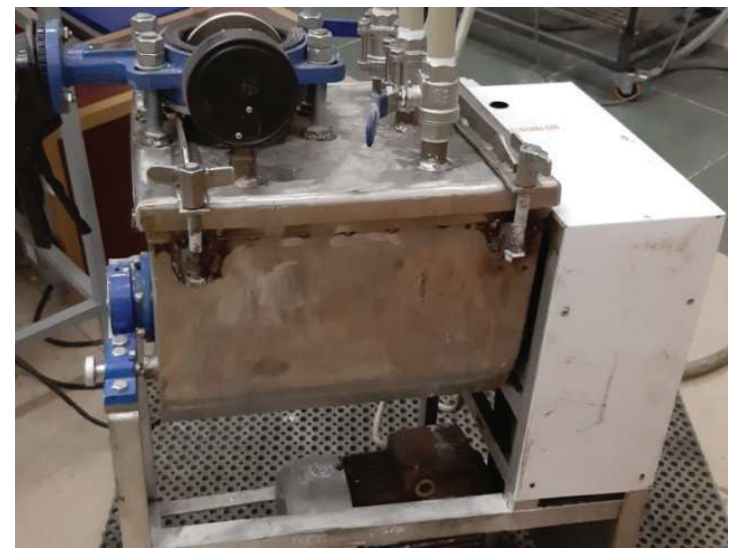

$a$

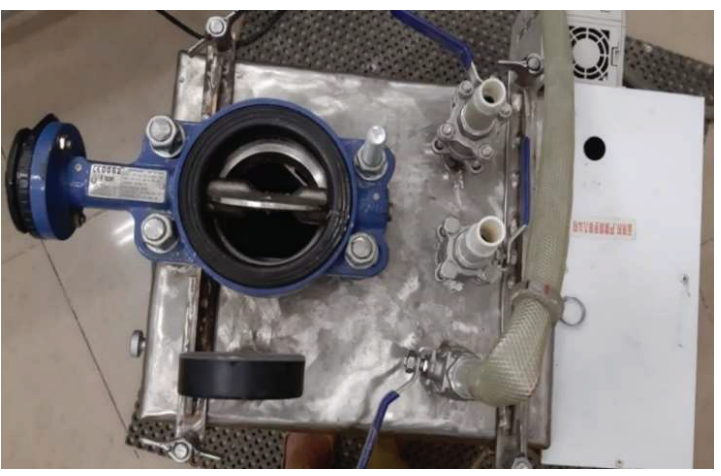

$b$

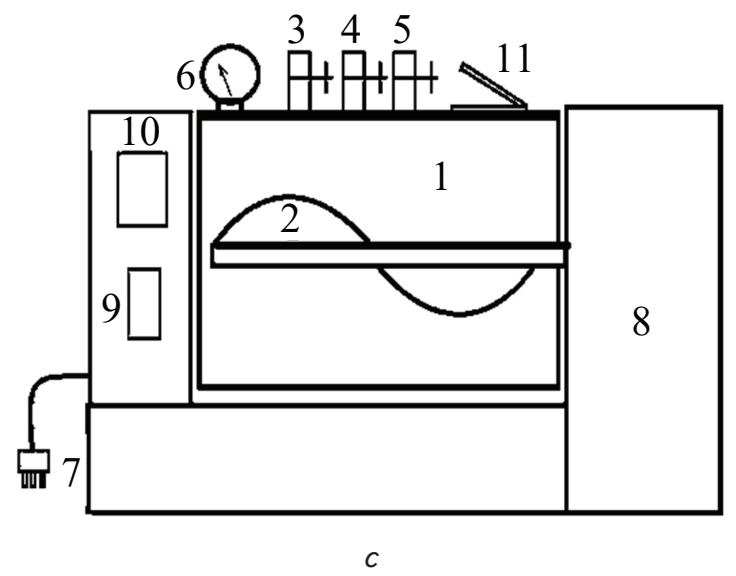

Fig. 1. lon-ozone cavitation unit for preparing dough with an accelerated cycle: $a$ - external view of the unit; $b$ - top view; c - unit diagram: 1 - container for preparing no yeast dough; 2 - bubble shaft; 3 - flour dispenser; 4 - dispenser

for water and other components; 5 - branch pipe for supplying ozone, molecular or atomic ions of oxygen in the air; 6 - pressure sensor; 7 - electric wire; 8 - electric drive; 9 - fuses; 10 - electrical converter; 11 - cavitator lever
In the technology of bakery production, one of the most important stages of the technological process is the loosening of the dough. Bakery products should have a uniform thin-walled crumb porosity. The porous structure of the dough, and, accordingly, the crumb of the product, can be obtained using biological, mechanical or chemical methods of loosening the semi-finished product. To obtain semi-finished products from wheat, a mixture of rye and wheat flour, a biological method is traditional, providing for their loosening as a result of alcoholic and lactic acid fermentation.

The dough was kneaded in the following ways:

- by the straight dough method (control) - according to the recipe;

- without activation of fermentation;

- in an accelerated way (with the addition of serum and ion-ozonized water);

- preparation of starter dough (part of ripe dough and ion-ozonized water);

- in an accelerated way with starter with the addition of whey and ion-ozonized water.

The dough was prepared by the straight dough method using ion-ozonized water.

The dough was prepared under pressure in a hermetically sealed ion-ozone kneading and whipping machine from wheat flour and additional raw materials according to the recipe.

The dough was kneaded for 5 minutes in an ion-ozone kneading and whipping machine of periodic action at a kneading body rotation frequency of $5 \mathrm{~s}^{-1}$. Then, the ionozonized mixture is fed into the mixing chamber under a pressure of $0.40 \mathrm{MPa}$ (cavitation) and the dough is beaten with different modes.

The kneaded dough was divided into two pieces and weighed with a mass of $400 \mathrm{~g}$ and $200 \mathrm{~g}$ and pressed down into molds. The dough was cut by hand. The pieces were placed immediately after molding into pre-lubricated molds: $400 \mathrm{~g}$ for baking tin bread, $200 \mathrm{~g}$ for baking hearth bread.

After cutting, the dough pieces were sent to the final proofing for 35-45 minutes. The products were baked in a humidified baking chamber at a temperature of $220{ }^{\circ} \mathrm{C}$. The baking time is $35-40$ minutes, depending on the weight of the products.

To accelerate the maturation of the dough, intensive kneading was applied and acidifiers and multicomponent bakery improvers were used. Part of the fermented dough of the previous batch and dry milk whey were used as acidifying additives. The main part of whey solids is lactose, the mass fraction of which is more than $70 \%$ of whey solids. Whey is a good source of various enzymes (protease, peptidase, lipase, phosphatase, lactase, etc.); vitamins (especially B vitamins); organic acids (lactic, acetic, formic, etc.) and other valuable substances.

Powdered milk whey was used in the work. Before use, the serum was diluted with water at a temperature of $35-45^{\circ} \mathrm{C}$ in a ratio of $1:(10-12)$. The amount of added dry whey is up to $10-25 \%$ of the total mass of flour used to make bread. Whey enriches breads and baked goods with essential amino acids, especially tryptophan and lysine, as well as calcium and phosphorus. At the same time, the yield of bread increases somewhat, its quality improves, and the nutritional value increases.

An urgent task in the production of no yeast bread with a reduced cycle is to obtain a pronounced aroma and color of the product. This can be achieved by adding starter to the recipe. In the work, fermented old dough was used as 
a culture. Such a dough is prepared from flour and water without additives and left for a while. It is possible to notice how various gases are formed in the dough. Under their influence, the dough turns sour, becomes loose, the fermentation process begins in it. Various enzymes are formed in the dough. If to add flour and water to such a dough, the fermentation process will intensify. The result is a dough that is fermentable, just like yeast. It should be noted that the resulting dough has a different smell and taste than yeast dough. In starter, along with useful substances, foreign microorganisms are formed, which reduce the lifting force of the dough, so it must be periodically refreshed by adding fresh flour and water. The moisture content of the starter is $56 \%$, the acidity is 12 degrees. To obtain a starter, flour and water are taken in a ratio of 10:6. The water should be at the same temperature as the dough $-24-26{ }^{\circ} \mathrm{C}$.

The no yeast dough on the ion-ozone cavitation unit is prepared in the following order:

1. The recipe components of the dough are fed through the inlet into the kneading body of the batch kneader, in which the kneading body is installed, driven by an electric motor by means of a speed variator. At the end of loading, the kneading body of the kneading machine is sealed with a lid and the dough is kneaded for 5 minutes at a kneading body rotation frequency of $5 \mathrm{~s}^{-1}$. Then the ionozone treatment was carried out using an overpressure of $0.40 \mathrm{MPa}$ (cavitation).

2. Next, the dough was churned and the dough was churned for 3-10 minutes at the kneading body rotation frequencies of $2-3,4-5$ and $7-8 \mathrm{~s}^{-1}$. When the recipe components are knocked down, the dough mass is saturated with air.

3. The dough prepared in this way is a foamy mass with stable physical and chemical characteristics. When churning, the process of churning dough from wheat flour of the first grade was investigated at the kneading body rotation frequencies of $2-3,4-5$ and $7-8 \mathrm{~s}^{-1}$ for $2-3,4-5$ and 7-10 minutes separately.

\section{Results of research of raw materials and bakery products}

\section{1. Technology for making no yeast bread from first grade wheat flour}

Organoleptic and physicochemical indicators of wheat flour of the first grade are given in Table 2.

The data of the chemical composition of the first grade wheat flour are given in Table 3.

From the data of Tables 2, 3 it can be seen that the quality indicators and chemical composition of the first grade wheat flour correspond to GOST 26574-85.

The dough from flour of the first grade was prepared according to the recipe and modes given in Table 4 .

A large amount of yeast also helps to loosen the dough in a relatively short time. In order to improve the taste properties of products and reduce the consumption of yeast, they are activated before kneading the straight dough.

For normal fermentation and maturation, an appropriate dough temperature is required, which depends on the temperature of the water or milk and the temperature of the flour. To activate the yeast, prepare a liquid water-flour mash containing $3 \ldots 5 \%$ flour from its total amount in the dough. The baking time for bread made with the activation of fermentation is significantly reduced.
To shorten the baking time, it is also advisable to enrich with products favorable for the development of yeast cells (whey, soy flour, ammonium salts).

Table 2

Quality indicators of first grade wheat flour

\begin{tabular}{|c|c|}
\hline Index & Results \\
\hline Colour & White \\
\hline Smell & $\begin{array}{c}\text { Characteristic of wheat flour, free of } \\
\text { foreign odors, not musty, not moldy }\end{array}$ \\
\hline Taste & $\begin{array}{c}\text { Characteristic of wheat flour, without } \\
\text { foreign tastes, not sour, not bitter }\end{array}$ \\
\hline \multicolumn{2}{|c|}{ Physicochemical: } \\
\hline Content of mineral impurities
\end{tabular}

Table 3

The chemical composition of the first grade flour

\begin{tabular}{|c|c|}
\hline Nutrients & Content in 100 g of product \\
\hline Protein, $\mathrm{g}$ & 13.69 \\
\hline Fat, $\mathrm{g}$ & 1.30 \\
\hline Carbohydrates, $\mathrm{g}$ & 72.14 \\
\hline Ash, $\mathrm{g}$ & 0.67 \\
\hline Energy value, $\mathrm{kcal}$ & 355 \\
\hline
\end{tabular}

This technology of filling the components is explained by the fact that the saline solution should not react with bacteria, since some of them would be neutralized and the fermentation process would be reduced.

When preparing the dough using starter, whey and ion-ozonized water, fermentation, colloidal and biochemical processes take place and due to this, the fermentation cycle and baking time are shortened.

Organoleptic (surface condition, consistency, degree of dryness, aroma) and physicochemical (temperature, humidity, acidity) indicators of dough for uncultureed bread, prepared by various recipes using the traditional method from first grade wheat flour are given in Table 5. A sample prepared in a safety-free manner served as a control (Table 1).

Further, the influence of different modes of rotation frequency and rotation time on the organoleptic and physicochemical parameters of the dough obtained on an ion-ozone cavitation unit for preparing dough with an accelerated cycle was investigated. The results are shown in Tables $6-8$. 
Table 4

Recipe and cooking modes for dough from wheat flour of the first grade for no yeast bread

\begin{tabular}{|c|c|c|c|c|c|}
\hline $\begin{array}{l}\text { Raw materials and pro- } \\
\text { cess indicators }\end{array}$ & Control & $\begin{array}{l}\text { Without activa- } \\
\text { tion of fermen- } \\
\text { tation }\end{array}$ & $\begin{array}{l}\text { With added whey } \\
\text { and ion-ozonized } \\
\text { water }\end{array}$ & $\begin{array}{l}\text { With starter and with the } \\
\text { addition of ion-ozonized } \\
\text { water }\end{array}$ & $\begin{array}{c}\text { Starter with the addition } \\
\text { of whey and ion-ozonized } \\
\text { water }\end{array}$ \\
\hline $\begin{array}{l}\text { Baking wheat flour } \\
1 \text { grade, kg }\end{array}$ & 100 & 100 & 100 & 100 & 100 \\
\hline Pressed bakery yeast, kg & 2.5 & 0 & 0 & 0 & 0 \\
\hline Dry milk whey, kg & 0 & 0 & 20 & 0 & 15 \\
\hline Starter, kg & 0 & 0 & 0 & 60 & 40 \\
\hline Table salt, kg & 1.5 & 1.5 & 1.5 & 1.5 & 1.5 \\
\hline Ozonized water, kg & \multicolumn{5}{|c|}{ According to the calculation } \\
\hline Initial temperature, ${ }^{\circ} \mathrm{C}$ & $28-32$ & $28-33$ & $28-33$ & $28-33$ & $28-33$ \\
\hline $\begin{array}{l}\text { Fermentation dura- } \\
\text { tion, min }\end{array}$ & 150 & 0 & 0 & 0 & 0 \\
\hline $\begin{array}{c}\text { Final acidity of the } \\
\text { dough, degrees, no more }\end{array}$ & $3.5-4.0$ & $3.5-3.6$ & $4.8-5.5$ & $5.5-6.5$ & $6-7$ \\
\hline $\begin{array}{l}\text { Moisture content of the } \\
\text { dough, \% no more }\end{array}$ & 44.5 & 44.5 & 44.5 & 44.5 & 44.5 \\
\hline Baking temperature, ${ }^{\circ} \mathrm{C}$ & 220 & 220 & 220 & 220 & 220 \\
\hline Duration of baking, min & $35-40$ & $45-50$ & $40-45$ & $35-40$ & $35-40$ \\
\hline
\end{tabular}

Table 5

Organoleptic and physicochemical indicators of the dough

\begin{tabular}{|c|c|c|c|c|c|}
\hline Dough indicators & Control & $\begin{array}{l}\text { Without activation } \\
\text { of fermentation }\end{array}$ & $\begin{array}{l}\text { With added whey and } \\
\text { ion-ozonized water }\end{array}$ & $\begin{array}{l}\text { With starter and with the ad- } \\
\text { dition of ion-ozonized water }\end{array}$ & $\begin{array}{l}\text { Starter with the addition of } \\
\text { whey and ion-ozonized water }\end{array}$ \\
\hline \multicolumn{6}{|c|}{ From wheat flour of the first grade } \\
\hline \multicolumn{6}{|c|}{ Organoleptic } \\
\hline Surface condition & convex & less convex & less convex & convex & convex \\
\hline Consistency & norms & strong & norms & norms & norms \\
\hline Dryness degree & dry & dry & dry & dry & dry \\
\hline Smell & alcoholic & no smell of alcohol & alcoholic & alcoholic & alcoholic \\
\hline \multicolumn{6}{|c|}{ Physicochemical } \\
\hline Temperature, ${ }^{\circ} \mathrm{C}$ & 31 & 32 & 33 & 33 & 33 \\
\hline $\begin{array}{l}\text { Acidity, degree: } \\
\text { initial }\end{array}$ & 3.5 & 3.5 & 4.8 & 5.5 & 6.0 \\
\hline ultimate & 4.0 & 3.6 & 5.5 & 6.5 & 6.5 \\
\hline Humidity, \% & 45.5 & 45.0 & 45.0 & 45.0 & 45.0 \\
\hline
\end{tabular}

As a result, the influence of the rotation frequency of the kneading body for 3-10 minutes on the organoleptic and physicochemical parameters of the dough made of first grade wheat flour was investigated.

The results of the study showed that the following modes and recipes are recommended for making beige bread:

1. Control sample of bread: churning for $3-5$ minutes at a kneading body rotation frequency of $2-3 \mathrm{~s}^{-1}$.

2. Bread cooked without fermentation activation: churning for $3-5$ minutes at a kneading body rotation frequency of $2-3 \mathrm{~s}^{-1}$.

3 . Bread prepared with the addition of whey and ionozonized water: churning for $3-5$ minutes at a kneading body rotation frequency of $2-3 \mathrm{~s}^{-1}$.

4 . Bread cooked with starter with the addition of ionozonized water: churning for $3-5$ minutes at a kneading body rotation frequency of $4-5 \mathrm{~s}^{-1}$.

5 . Bread prepared with the addition of whey and ionozonized water: churning for $3-5$ minutes at a kneading body rotation frequency of $4-5 \mathrm{~s}^{-1}$.
Wheat flour dough is formed by mixing it with water. Their ratio, the presence of recipe components affects the structure of the dough and the individual characteristics of the resulting finished product.

The process of dough formation is due to the chemical properties of flour (chemical composition of grain), the role of its individual constituent substances, enzymes. The dominant role belongs to proteins and starch of flour.

Along with water- and salt-soluble proteins that form colloidal solutions in the dough, flour contains limitedly soluble (swelling) proteins-prolamins (gliadin) and glutelins (glutenin). These proteins are polymers and consist of a-amino acid residues. Polymer molecules of proteins with physiological value consist of 20 amino acids.

The presence of polar and non-polar groups of atoms in protein molecules gives them the properties of surface activity and high reactivity. In the dough, proteins interact with water, carbohydrates, fats. A complex structure, strong bonds give proteins significant elasticity and strength. The content of non-polar atomic groups with weak dispersion bonds ensures high elasticity of proteins. 
Table 6

Influence of the rotational speed of the kneading body for 3-5 minutes on the organoleptic and physicochemical parameters of the dough from first grade wheat flour

\begin{tabular}{|c|c|c|c|c|c|}
\hline Dough indicators & Control & $\begin{array}{c}\text { Without activation } \\
\text { of fermentation }\end{array}$ & $\begin{array}{c}\text { With added whey and } \\
\text { ion-ozonized water }\end{array}$ & $\begin{array}{l}\text { With starter and with the ad- } \\
\text { dition of ion-ozonized water }\end{array}$ & $\begin{array}{l}\text { Starter with the addition of } \\
\text { whey and ion-ozonized water }\end{array}$ \\
\hline \multicolumn{6}{|c|}{ At a kneading body rotation frequency of $2.0-3.0 \mathrm{~s}^{-1}$} \\
\hline \multicolumn{6}{|c|}{ Organoleptic } \\
\hline Surface condition & convex & less convex & less convex & less convex & less convex \\
\hline Consistency & norms & strong & norms & norms & norms \\
\hline Dryness degree & dry & dry & dry & dry & dry \\
\hline Smell & alcoholic & no smell of alcohol & alcoholic & alcoholic & alcoholic \\
\hline \multicolumn{6}{|c|}{ Physicochemical } \\
\hline Temperature, ${ }^{\circ} \mathrm{C}$ & 31 & 30 & 31 & 31 & 31 \\
\hline \multicolumn{6}{|l|}{ Acidity, degree: } \\
\hline initial & 3.5 & 3.1 & 3.2 & 3.3 & 4.0 \\
\hline ultimate & 4.0 & 3.3 & 4.5 & 5.6 & 6.5 \\
\hline Humidity, \% & 44.5 & 43.0 & 44.0 & 44.0 & 44.0 \\
\hline \multicolumn{6}{|c|}{ At a kneading body rotation frequency of $4.0-5.0 \mathrm{~s}^{-1}$} \\
\hline \multicolumn{6}{|c|}{ Organoleptic } \\
\hline Surface condition & convex & less convex & less convex & convex & convex \\
\hline Consistency & norms & strong & norms & norms & norms \\
\hline Dryness degree & dry & dry & dry & dry & dry \\
\hline Smell & alcoholic & no smell of alcohol & alcoholic & alcoholic & alcoholic \\
\hline \multicolumn{6}{|c|}{ Physicochemical } \\
\hline Temperature & 31 & 30 & 32 & 32 & 32 \\
\hline \multicolumn{6}{|l|}{ Acidity, degree: } \\
\hline initial & 3.5 & 4.5 & 5.5 & 6.0 & 6.5 \\
\hline ultimate & 4.0 & 4.8 & 6.0 & 6.5 & 6.5 \\
\hline Humidity, \% & 44.5 & 45.0 & 45.0 & 45.0 & 45.0 \\
\hline \multicolumn{6}{|c|}{ At a kneading body rotation frequency of $7.0-8.0 \mathrm{~s}^{-1}$} \\
\hline \multicolumn{6}{|c|}{$\begin{array}{l}\text { Organoleptic } \\
\end{array}$} \\
\hline Surface condition & convex & less convex & less convex & convex & convex \\
\hline Consistency & norms & norms & norms & norms & rather weak \\
\hline Dryness degree & dry & dry & dry & dry & dry \\
\hline Smell & alcoholic & no smell of alcohol & alcoholic & alcoholic & alcoholic \\
\hline \multicolumn{6}{|c|}{ Physicochemical } \\
\hline Temperature & 31 & 32 & 33 & 33 & 33 \\
\hline \multicolumn{6}{|l|}{ Acidity, degree: } \\
\hline initial & 3.5 & 4.5 & 5.5 & 6.0 & 6.5 \\
\hline ultimate & 4.0 & 4.8 & 6.0 & 6.5 & 6.5 \\
\hline Humidity, $\%$ & 44.5 & 45.0 & 45.0 & 45.0 & 45.0 \\
\hline
\end{tabular}

Table 7

Influence of the rotation frequency of the kneading body for 5-7 minutes on the organoleptic and physicochemical parameters of the dough made of first grade wheat flour

\begin{tabular}{|c|c|c|c|c|c|}
\hline Dough indicators & Control & $\begin{array}{c}\text { Without activation } \\
\text { of fermentation }\end{array}$ & $\begin{array}{c}\text { With added whey and } \\
\text { ion-ozonized water }\end{array}$ & $\begin{array}{c}\text { With starter and with the ad- } \\
\text { dition of ion-ozonized water }\end{array}$ & $\begin{array}{c}\text { Starter with the addition of } \\
\text { whey and ion-ozonized water }\end{array}$ \\
\hline 1 & 2 & 3 & 4 & 5 & 6 \\
\hline \multicolumn{7}{|c|}{ At a kneading body rotation frequency of 2.0-3.0 s ${ }^{-1}$} \\
\hline \multicolumn{7}{|c|}{ Organoleptic } \\
\hline Surface condition & convex & less convex & less convex & convex & convex \\
\hline Consistency & norms & strong & norms & norms & dry \\
\hline Dryness degree & dry & dry & dry & dry & alcoholic \\
\hline Smell & alcoholic & no smell of alcohol & alcoholic & alcoholic & \\
\hline
\end{tabular}


Continuation of Table 7

\begin{tabular}{|c|c|c|c|c|c|}
\hline 1 & 2 & 3 & 4 & 5 & 6 \\
\hline \multicolumn{6}{|c|}{ Physicochemical } \\
\hline Temperature, ${ }^{\circ} \mathrm{C}$ & 31 & 31 & 32 & 32 & 32 \\
\hline \multicolumn{6}{|l|}{ Acidity, degree: } \\
\hline initial & 3.5 & 3.1 & 3.2 & 3.3 & 4.0 \\
\hline ultimate & 4.0 & 3.3 & 4.5 & 5.6 & 6.5 \\
\hline Humidity, \% & 44.5 & 43.0 & 44.0 & 44,0 & 44,0 \\
\hline \multicolumn{6}{|c|}{ At a kneading body rotation frequency of $4.0-5.0 \mathrm{~s}^{-1}$} \\
\hline \multicolumn{6}{|c|}{ Organoleptic } \\
\hline Surface condition & convex & less convex & less convex & convex & convex \\
\hline Consistency & norms & strong & norms & norms & norms \\
\hline Dryness degree & dry & dry & dry & dry & dry \\
\hline Smell & alcoholic & no smell of alcohol & alcoholic & alcoholic & alcoholic \\
\hline \multicolumn{6}{|c|}{ Physicochemical } \\
\hline Temperature & 31 & 32 & 33 & 33 & 33 \\
\hline \multicolumn{6}{|l|}{ Acidity, degree: } \\
\hline initial & 3.5 & 3.5 & 4.8 & 5.5 & 6.0 \\
\hline ultimate & 4.0 & 3.6 & 5.5 & 6.5 & 6.5 \\
\hline Humidity, \% & 44.5 & 45.0 & 45.0 & 45.0 & 45.0 \\
\hline \multicolumn{6}{|c|}{ At a kneading body rotation frequency of $7.0-8.0 \mathrm{~s}^{-1}$} \\
\hline \multicolumn{6}{|c|}{ Organoleptic } \\
\hline Surface condition & convex & less convex & less convex & convex & convex \\
\hline Consistency & norms & rather weak & rather weak & norms & norms \\
\hline Dryness degree & dry & dry & dry & dry & dry \\
\hline Smell & alcoholic & no smell of alcohol & alcoholic & alcoholic & alcoholic \\
\hline \multicolumn{6}{|c|}{ Physicochemical } \\
\hline Temperature & 31 & 33 & 35 & 35 & 35 \\
\hline \multicolumn{6}{|l|}{ Acidity, degree: } \\
\hline initial & 3.5 & 4.5 & 5.5 & 6.0 & 6.0 \\
\hline ultimate & 4.0 & 4.8 & 6.0 & 6.5 & 6.5 \\
\hline Humidity, \% & 44.5 & 45.0 & 45.0 & 45.0 & 45.0 \\
\hline
\end{tabular}

Table 8

Influence of the rotation frequency of the kneading body for 7-10 minutes on the organoleptic and physicochemical parameters of the dough made of first grade wheat flour

\begin{tabular}{|c|c|c|c|c|c|}
\hline Dough indicators & Control & \begin{tabular}{|c|}
$\begin{array}{c}\text { Without activation of } \\
\text { fermentation }\end{array}$ \\
\end{tabular} & $\begin{array}{l}\text { With added whey and } \\
\text { ion-ozonized water }\end{array}$ & $\begin{array}{c}\text { With starter and with the } \\
\text { addition of ion-ozonized water }\end{array}$ & $\begin{array}{l}\text { Starter with the addition of } \\
\text { whey and ion-ozonized water }\end{array}$ \\
\hline 1 & 2 & 3 & 4 & 5 & 6 \\
\hline \multicolumn{6}{|c|}{ At a kneading body rotation frequency of $2.0-3.0 \mathrm{~s}^{-1}$} \\
\hline \multicolumn{6}{|c|}{$\begin{array}{c}\text { Organoleptic } \\
\end{array}$} \\
\hline Surface condition & convex & less convex & less convex & convex & convex \\
\hline Consistency & norms & norms & norms & norms & norms \\
\hline Dryness degree & dry & dry & dry & dry & dry \\
\hline Smell & alcoholic & no smell of alcohol & alcoholic & alcoholic & alcoholic \\
\hline \multicolumn{6}{|c|}{ Physicochemical } \\
\hline Temperature, ${ }^{\circ} \mathrm{C}$ & 31 & 33 & 34 & 34 & 34 \\
\hline Acidity, degree: & & & & & \\
\hline initial & 3.5 & 3.2 & 3.8 & 3.5 & 4.5 \\
\hline ultimate & 4.0 & 3.3 & 4.8 & 5.8 & 7.0 \\
\hline Humidity, \% & 44.5 & 43.0 & \begin{tabular}{|l|l}
44.0 \\
\end{tabular} & 44.0 & 44.0 \\
\hline \multicolumn{6}{|c|}{ At a kneading body rotation frequency of $4.0-5.0 \mathrm{~s}^{-1}$} \\
\hline \multicolumn{6}{|c|}{$\begin{array}{c}\text { Organoleptic } \\
\end{array}$} \\
\hline Surface condition & convex & less convex & less convex & convex & convex \\
\hline Consistency & norms & strong & norms & norms & norms \\
\hline Dryness degree & dry & dry & dry & dry & dry \\
\hline Smell & alcoholic & no smell of alcohol & alcoholic & alcoholic & alcoholic \\
\hline
\end{tabular}


Continuation of Table 8

\begin{tabular}{|c|c|c|c|c|c|}
\hline 1 & 2 & 3 & 4 & 5 & 6 \\
\hline \multicolumn{6}{|c|}{ Physicochemical } \\
\hline Temperature & 31 & 34 & 37 & 37 & 37 \\
\hline \multicolumn{6}{|l|}{ Acidity, degree: } \\
\hline initial & 4.5 & 5.0 & 6.0 & 6.0 & 6.0 \\
\hline ultimate & 5.0 & 5.2 & 6.3 & 6.5 & 6.5 \\
\hline Humidity, \% & 44.5 & 45.0 & 45.0 & 45.0 & 45.0 \\
\hline \multicolumn{6}{|c|}{ At a kneading body rotation frequency of $7.0-8.0 \mathrm{~s}^{-1}$} \\
\hline \multicolumn{6}{|c|}{ Organoleptic } \\
\hline Surface condition & convex & less convex & less convex & convex & rather weak \\
\hline Consistency & norms & rather weak & rather weak & rather weak & dry \\
\hline Dryness degree & dry & dry & dry & dry & alcoholic \\
\hline Smell & alcoholic & no smell of alcohol & alcoholic & alcoholic & rather weak \\
\hline \multicolumn{6}{|c|}{ Physicochemical } \\
\hline Temperature & 31 & 36 & 40 & 40 & 40 \\
\hline Acidity, degree: & & & & & \\
\hline initial & 4.5 & 5.5 & 6.5 & 7.0 & 7.5 \\
\hline ultimate & 5.0 & 5.9 & 6.8 & 7.5 & 8.5 \\
\hline Humidity, \% & 44.5 & 45.0 & 45.0 & 45.0 & 45.0 \\
\hline
\end{tabular}

The hydrophilic properties of the protein are explained by the presence of numerous ionic and polar atomic groups in the molecules and the ability to mechanically capture a significant amount of free moisture during watering. The absorption of water by protein substances occurs in two stages.

At the first stage of swelling, small amounts of water are bound due to the activity of hydrophilic groups of flour particles and aqueous solvation shells are formed. The interaction of ion-ozonized water with hydrophilic groups occurs not only on the surface of flour particles, but also in the bulk.

The main protein binding of ion-ozonized water occurs at the second stage - over $200 \%$ due to the so-called osmotic swelling. It consists in the fact that water molecules, as a result of diffusion, penetrate into the gluten particles. The second stage of swelling is accompanied by a significant increase in the volume of flour particles and passes without heat release

An important property of hydrated protein molecules is a change in the shape of molecules, or denaturation, under conditions of heating, stirring, churning, as well as chemical effects of oxidants, reducing agents, etc. Denaturation of hydrated proteins can be both reversible and irreversible. It depends on the intensity of the physicochemical effect on proteins.

Mechanical effects on protein molecules lead to deformation and orientation in the plane of the direction of these effects. They form fibers and films in the bulk, stabilizing (emulsifying) water-fat structures. When churned in the presence of ion-ozone, protein molecules are oriented at the interface between the phases "liquid-ion-ozone", forming foam-like structures. At the same time, they stretch and denature.

With intensive heating of hydrated protein molecules, irreversible denaturation of proteins occurs. This process takes place when baking. The mechanical properties of hydrated and denatured proteins change. From soft elastic hy- drated gels, they turn into hard, elastic, durable gels, almost devoid of plasticity (fluidity).

Wheat proteins swelling in water (gliadin and glutenin) can be washed out of the dough with water in a partially denatured form, forming gluten. Thus, the protein fractions swollen in water stick together, forming a highly swollen colloidal jelly - gluten.

The structure of flour dough is determined not only by the amount of proteins, but mainly by their structure and mechanical properties, these properties affect the ability of flour proteins to retain different amounts of water, that is, the water absorption capacity of flour. One part of flour proteins, when swollen in cold ion-ozonized water, can hold $2 . .2 .5$ parts of water, i.e., the amount of retained ion-ozonized water is $2 \ldots 2.5$ times the mass of proteins.

The properties of flour proteins, their molecular weight, gluten structure, mechanical properties are influenced by the natural properties and conditions of grain ripening, flour yield, and its dispersion. The structure of raw gluten proteins affects not only the properties of the dough, but also the yield and properties of products. These indicators are also significantly influenced by starch and other flour compounds.

Thus, the addition of starter, whey and ion-ozonized water to the recipe, as well as the churning time and the rotational speed of the kneading body of the kneading plant, significantly affects the preparation of bread.

5. 2. Investigation of the quality of no yeast bread made from wheat flour of the first grade

When developing the technology of no yeast bread, the study of the quality of the finished product is of practical importance.

Analysis of the quality of bread prepared with optimal modes and recipes was carried out 14-16 hours after baking. The results of the study of the quality of no yeast bread made from wheat flour of the first grade are presented in Table 9. 
The quality of no yeast bread made from wheat flour of the first grade

\begin{tabular}{|c|c|c|c|c|c|}
\hline $\begin{array}{c}\text { Dough } \\
\text { indicators }\end{array}$ & Control & $\begin{array}{c}\text { Without activation } \\
\text { of fermentation }\end{array}$ & $\begin{array}{l}\text { With added whey and } \\
\text { ion-ozonized water }\end{array}$ & $\begin{array}{l}\text { With starter and with the ad- } \\
\text { dition of ion-ozonized water }\end{array}$ & $\begin{array}{l}\text { Starter with the addition of } \\
\text { whey and ion-ozonized water }\end{array}$ \\
\hline \multicolumn{6}{|c|}{ Organoleptic } \\
\hline $\begin{array}{l}\text { Appearance: } \\
\text { shape }\end{array}$ & correct & correct & correct & correct & correct \\
\hline peel color & light brown & pale gray & light brown & light brown & light brown \\
\hline $\begin{array}{c}\text { surface } \\
\text { condition }\end{array}$ & smooth & $\begin{array}{l}\text { with cracks and } \\
\text { explosions }\end{array}$ & smooth & smooth & smooth \\
\hline $\begin{array}{c}\text { Crumb } \\
\text { condition: } \\
\text { elasticity }\end{array}$ & elastic & less elastic & elastic & elastic & elastic \\
\hline Colour & light & $\begin{array}{c}\text { light with a gray } \\
\text { tint }\end{array}$ & $\begin{array}{l}\text { light with a yellowish } \\
\text { tinge }\end{array}$ & light & light with a yellowish tinge \\
\hline porosity & $\begin{array}{l}\text { uniform, } \\
\text { medium }\end{array}$ & uniform, fine & uniform, medium & uniform, medium & uniform, medium \\
\hline \multicolumn{6}{|c|}{ Physicochemical } \\
\hline $\begin{array}{l}\text { Humidi- } \\
\text { ty, } \%\end{array}$ & 43.0 & 42.5 & 43.0 & 43.0 & 43.0 \\
\hline $\begin{array}{c}\text { Acidity, } \\
\text { degree }\end{array}$ & 3.5 & 3.0 & 4.0 & 5.0 & 5.5 \\
\hline Porosity, \% & 72 & 55 & 65 & 68 & 70 \\
\hline $\begin{array}{c}\text { Specific } \\
\text { volume, } \\
\mathrm{cm}^{3} / \mathrm{g}\end{array}$ & 3.5 & 2.5 & 2.7 & 3.5 & 3.7 \\
\hline $\begin{array}{c}\text { Form sta- } \\
\text { bility, H/D }\end{array}$ & 0.50 & 0.32 & 0.35 & 0.40 & 0.45 \\
\hline
\end{tabular}

\section{3. Study of nutritional value and safety assessment} of no yeast bread made from first grade wheat flour

To study the nutritional value, as well as the safety of the developed varieties of bread, laboratory baking of bread from first grade wheat flour was carried out in an accelerated way. The dough is prepared with the addition of whey and ion-ozonized water with an ozone concentration of $2 \mathrm{mg} / \mathrm{l}$; with the addition of starter and ionozonized water; in an accelerated way with starter with the addition of whey and ion-ozonized water. The controls were samples of wheat bread made from first grade wheat flour using ordinary drinking water. After 14 hours of storage of the bread after baking, the content of protein, fat, carbohydrates and fiber, microbiological indicators such as yeast and mold were determined.

The results of the study of the chemical composition of the developed no yeast bakery products using ion-ozonized water, whey and starter are given in Table 10 .

Based on the results obtained, it was determined that bread made with starter with the addition of dry milk whey and ion-ozonized water showed the best qualities and its recipe is proposed for production. Such bread should be stored at a temperature of no more than $25{ }^{\circ} \mathrm{C}$ and a relative humidity of no more than $85 \%$. A comparative photo of a control sample of bread prepared by the traditional method and bread made with starter with the addition of whey powder and ion-ozonized water are shown in Fig. 2.

A control sample of bread was prepared by the traditional method in a safety-free way according to the recipe indicated in Table 1. The optimal bread options were prepared in the following modes:

1. Churning was carried out within $3-5$ minutes.

2. When the rotation speed of the kneading body is $4-5 \mathrm{~s}^{-1}$.
These modes were used to obtain no yeast dough prepared from first grade flour with starter with the addition of whey and ion-ozonized water.

An important advantage of this method is its technological flexibility and economic efficiency of the technology.

The no yeast dough preparation method, in comparison with the traditional one, has a number of economic and organizational advantages: the technological cycle is reduced by $20-30 \%$, which means that the need for fermentation tanks, production area and equipment is reduced. The average cost of control traditional bread is 120 tenge, and bread made from first grade flour with starter with the addition of whey and ion-ozonized water is 100 tenge. This difference is due to shorter fermentation and dough preparation times and thus lower energy costs. At the same time, healthy bread and bakery products with a pleasant taste and aromatic smell will be obtained.

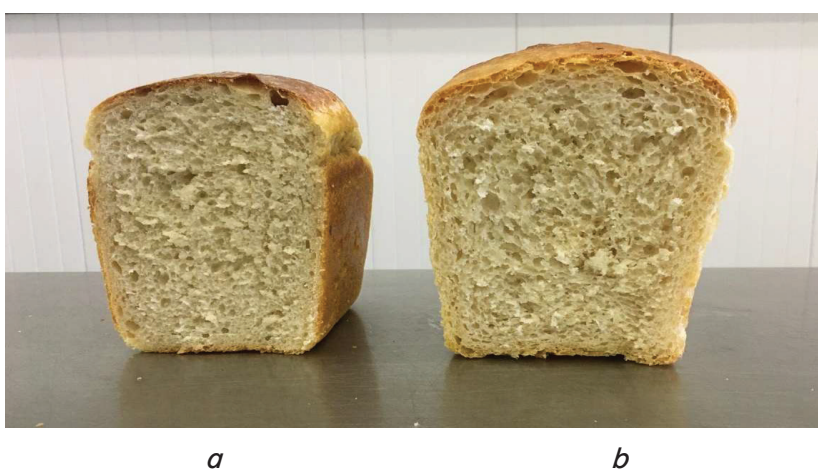

Fig. 2. Wheat bread made from first grade flour: $a-$ control sample of bread prepared by the traditional method; $b$ - bread made with starter using dry milk whey and ion-ozonized water 
Nutritional value and microbiological indicators of bread made from first grade flour

\begin{tabular}{|c|c|c|c|c|c|}
\hline Dough indicators & Control & $\begin{array}{c}\text { Without } \\
\text { activation of } \\
\text { fermentation }\end{array}$ & $\begin{array}{l}\text { With added whey } \\
\text { and ion-ozonized } \\
\text { water }\end{array}$ & $\begin{array}{l}\text { With starter and with } \\
\text { the addition of ion- } \\
\text { ozonized water }\end{array}$ & $\begin{array}{l}\text { Starter with the } \\
\text { addition of whey and } \\
\text { ion-ozonized water }\end{array}$ \\
\hline \multicolumn{6}{|c|}{ Physical and chemical indicators: } \\
\hline mass fraction of protein, $\%$ & 7.45 & 8.48 & 8.21 & 8.77 & 9.17 \\
\hline mass fraction of fat, $\%$ & 0.7 & 0.385 & 0.36 & 0.20 & 4.29 \\
\hline mass fraction of fiber, $\%$ & 2.83 & 3.25 & 4.06 & 2.36 & 1.2 \\
\hline ash content, $\%$ & 1.17 & 1.13 & 1.43 & 1.27 & 0.37 \\
\hline $\begin{array}{c}\text { mass fraction of carbohy- } \\
\text { drates, } \%\end{array}$ & 37.3 & 38.27 & 37.62 & 40.81 & 47.30 \\
\hline \multicolumn{6}{|c|}{ Microbiological indicators: } \\
\hline yeast, $\mathrm{CFU} / \mathrm{g}$, no more & $\begin{array}{l}\text { Continuous } \\
\text { growth }\end{array}$ & 17 & 2 & 2 & 36 \\
\hline mold, CFU/g, no more & not found & not found & not found & not found & not found \\
\hline
\end{tabular}

\section{Discussion of the results of the study of no yeast dough obtained by the accelerated method}

From the data of Table 5 it can be seen that the organoleptic and physicochemical indicators of the dough made from wheat flour of the first grade were as follows:

- the state of the crumb of the dough prepared with starter and starter with the addition of milk whey were convex as a control sample. The crumb state of the dough prepared without activating fermentation and with the addition of whey was less convex;

- the consistency of the dough, prepared without activating fermentation, was strong, while the rest was normal as a control sample;

- the degree of dryness in all samples was almost the same;

- by aroma: in the dough prepared without activating fermentation, there was no smell of alcohol, while the rest had an alcoholic aroma, like the control sample;

- the temperature of the control dough sample was $31{ }^{\circ} \mathrm{C}$, and for the rest of the tested dough samples it was $32-33{ }^{\circ} \mathrm{C}$;

- the initial acidity of the control sample was 3.5 degrees, and the final acidity was 4.0 degrees. The initial acidity of the dough prepared without activating fermentation was 3.5 degrees, the final acidity was 3.6 degrees. The initial acidity of the dough prepared with the addition of milk whey was 4.8 degrees, the final acidity was 5.5 degrees. The initial acidity of the dough prepared with starter was 5.5 degrees, the final acidity was 6.5 degrees. The initial acidity of the dough, prepared without activating fermentation, was 6.0 degrees, the final acidity was 6.5 degrees;

- the moisture content of all samples was the same.

From the data of Tables $6-8$ it can be seen that the rotation frequency of the kneading body and the processing time significantly affect the organoleptic and physicochemical characteristics of the dough made from first grade wheat flour. The comparative characteristics were as follows:

- the surface condition of the dough prepared from liquid starter and liquid starter with the addition of milk whey was the same as that of the control dough sample, that is, the surface was convex. It was less convex only at a kneading body rotation frequency of $2.0-3.0 \mathrm{~s}^{-1}$ for 3-5 minutes;
- the consistency of the control dough samples was normal in all modes. The consistency of the dough without activation of fermentation was strong at a kneading body rotation frequency of $2.0-3.0 \mathrm{~s}^{-1}$ and $4.0-5.0 \mathrm{~s}^{-1}$ for 3-5 minutes. At a kneading body rotation frequency of $2.0-3.0 \mathrm{~s}^{-1}$ and $4.0-5.0 \mathrm{~s}^{-1}$ for $5-7$ minutes and at a kneading body rotation frequency of $4.0-5.0 \mathrm{~s}^{-1}$ for $7-10$ minutes. And at a kneading body rotation frequency of $7.0-8.0 \mathrm{~s}^{-1}$ for $5-7$ minutes and $7-10$ minutes they were rather weak. This means that the dough prepared with these modes was of poor quality. The consistency of the other types of dough, prepared without activating fermentation, was normal. The consistency of the dough with the addition of whey at a kneading body rotation frequency of $7.0-8.0 \mathrm{~s}^{-1}$ for $5-7$ minutes and $7-10$ minutes was rather weak. The consistency of the other doughs prepared with the addition of whey was normal. The consistency of the dough prepared with starter at a kneading body rotation frequency of $7.0-8.0 \mathrm{~s}^{-1}$ for $5-7$ minutes and $7-10$ minutes was rather weak. The consistency of the other starter doughs was normal. The consistency of the dough prepared with starter with the addition of whey at a kneading body rotation frequency of $7.0-8.0 \mathrm{~s}^{-1}$ for $3-5$ minutes, 5-7 minutes and 7-10 minutes was rather weak. The consistency of the other starter doughs was normal:

- the degree of dryness in all samples was the same;

- by aroma: in the dough prepared without activating fermentation, there was no smell of alcohol, and the rest of the samples had a pronounced smell of alcohol;

- the temperature ranged from 30 to $40{ }^{\circ} \mathrm{C}$;

- the initial acidity of the control samples ranged from 3.5 to 4.5 degrees, and the final acidity ranged from 4.0 to 5.0 degrees. The initial acidity of the dough prepared without activating fermentation ranged from 3.1 to 5.5 degrees, and the final acidity ranged from 3.3 to 5.9 degrees. The initial acidity of the dough prepared with the addition of whey ranged from 3.2 to 6.5 degrees, and the final acidity ranged from 4.5 to 6.8 degrees. The initial acidity of the dough prepared with starter ranged from 3.3 to 6.5 degrees, and the final acidity ranged from 5.6 to 6.5 degrees. The initial acidity of the dough prepared with starter with the addition of whey ranged from 4.0 to 6.5 degrees, and the final acidity ranged from 6.0 to 6.5 degrees. As a result, it was seen that with an increase in the frequency of rotation and time, the acidity increases. 
The moisture content of the dough ranged from $43 \%$ to $45 \%$.

The results of the study of organoleptic and physicochemical indicators showed that churning for 3-5 minutes at a kneading body rotation frequency of $4-5 \mathrm{~s}^{-1}$ is the optimal mode for obtaining a no yeast dough.

From Table 9 it can be seen that all samples have the correct shape, the crust is smooth, without cracks and explosions, the crumb is characterized by a uniform arrangement of pores and good elasticity, except for a bread sample prepared without fermentation activation. Bread cooked without fermentation has a pale gray crust and less elastic crumb. The moisture content of the bread in all samples was approximately $43.0 \%$. The acidity ranged from 3 to 6.5 degrees. The highest acidity was found in the sample prepared with a starter with added whey. Therefore, this mode is not recommended for baking no yeast bread. The specific volume of bread varied from 2.5 to $3.85 \mathrm{~cm}^{3} / \mathrm{g}$, the lowest specific volume of bread was in the samples of bread prepared without yeast and with the addition of whey 2.5 and 2.7 , respectively.

Similar changes were observed in the porosity index. The porosity of the bread varied from 55 to $70 \%$, the lowest porosity was in the samples of bread prepared without fermentation activation and with the addition of whey, 55 and $65 \%$, respectively. Whereas in the control sample, the porosity was $72 \%$.

Form stability of the bread ranged from 0.32 to 0.5 . The lowest dimensional stability was in bread prepared without fermentation activation and amounted to 0.32 , in bread with added whey it was 0.35 , in bread prepared with starter it was 0.4 . Also, in bread made with starter with the addition of whey, the dimensional stability was 0.45 . And in the control sample, this figure was 0.5 . According to normative documents, the dimensional stability of bread baked from first grade wheat flour is $0.42-0.5$ and second grade $0.34-0.45$. The results obtained showed that the dimensional stability of all bread samples correspond to the standards.

Analysis of the obtained data in Table 10 indicates that in bread made with starter with the addition of whey and ion-ozonized water, the content of protein and fat increased. An increase in the nutritional value of bakery products indicates that whey contains such valuable trace elements as potassium, calcium, magnesium, phosphorus and is saturated with valuable proteins. It also contains a lot of vitamins, in particular vitamins A, E, PP, C and group B. In total, it contains more than 200 types of nutrients and biologically active elements and vitamins.

Mold is the most common type of microbiological spoilage of food, including baked goods. The source of bread mold is the development of molds of the genus Asperqillus (A. flavus, A. fumigatus, A. niger, Aochraceus), Mucor (M. mucedo, M. pusius, M. spinosus), Penicilliun (P. crustosum, P. expansum), Rhizopusnigricans, Geotrichumcandidum. For bread to mold, it is necessary to have appropriate conditions favorable for mold development. So, the development and growth of molds is possible at temperatures from 5 to $50{ }^{\circ} \mathrm{C}$.

The acidity of the product also serves as a reason for the development of microorganisms in it: the optimal $\mathrm{pH}$ for the formation of molds is from 4.5 to 5.5. Therefore, the acidity of baked goods does not limit the development of mold.

Yeast in comparison with the control sample was significantly reduced in all studied samples. No mold was found in all samples.
The essence of the work is to develop an assortment of bread products from wheat flour based on ion-ozone cavitation technology for dough preparation. This technology contributes to improving the quality, safety of finished products, reducing the technological process of production (no fermentation and proofing, and therefore no equipment) and the elimination of yeast during dough preparation.

The production of bread using this technology is carried out as follows: the first stage includes the preparation and dosing of raw materials for production. At the second stage, the components are mixed in a cavitation tank with a rotating stirrer to the required turnover, regulated by electrical frequencies according to the established dough time. At the third stage, ion-ozone air with a set concentration and pressure is supplied, a certain time is maintained, and the excess pressure is abruptly released to the level of atmospheric air. At the fourth stage, the complete loosening of the dough is completed in the cavitation tank, the physical, rheological, biochemical properties and the formation of the dough without yeast are improved. At the fifth stage, the kneaded dough is divided, shaped and sent to baking, and at the sixth stage, packaging and storage are carried out.

The advantage of the proposed technology is:

- reducing the cost of production by eliminating yeast and reducing the technological process of production;

- increase in bread yield by $14-18 \%$;

- an increase in labor productivity by more than $2-3$ times and an increase in the company's income by 2 times.

The described method of preparing dough with intensive kneading of the dough, in which the fermentation period before cutting is shortened, has technical, technological and economic advantages. The need to install expensive dough fermentation units is eliminated, which significantly reduces the area of the dough preparation department. In general, the duration of the entire dough preparation process is shortened and the transfer of production from the production of one type of product to another is simplified.

The implementation of the obtained research results will expand the range of no yeast bakery products on the market all over the world. An opportunity is created to quickly organize and create the developed technologies on the basis of existing small and medium-sized enterprises, ensuring a quick payback of the created technological lines.

\section{Conclusions}

1. The quality indicators and chemical composition of the first grade wheat flour have been investigated and it has been established that the obtained flour results correspond to GOST 26574-85. The formulations and modes of preparation of dough from wheat flour of the first grade for no yeast bread have been established. The influence of the rotational speed of the kneading body for $3-5,5-7$ and 7-10 minutes on the organoleptic and physicochemical parameters of the dough made from wheat flour of the first grade was determined. The results showed that the rotation frequency of the kneading body $2.0-3.0 \mathrm{~s}^{-1} 4.0-5.0 \mathrm{~s}^{-1}$ and $7.0-8.0 \mathrm{~s}^{-1}$ for $3-5,5-7$ and $7-10$ minutes have a special effect on the organoleptic and physicochemical characteristics of the first grade wheat flour dough. The optimal modes and recipes for the preparation of no yeast dough have been established. 
2. The analysis of the quality of no yeast bread made from wheat flour of the first grade has been carried out. All the samples obtained have the correct shape, the crust is smooth, without cracks and breaks, the crumb is characterized by a uniform arrangement of pores and good elasticity, except for a sample of bread prepared without fermentation activation. Bread cooked without fermentation has a pale gray crust and less elastic crumb. The moisture content of the bread in all samples was approximately $43.0 \%$. The acidity ranged from 3 to 6.5 degrees. The specific volume of bread varied from 2.5 to $3.85 \mathrm{~cm}^{3} / \mathrm{g}$. The porosity of the bread varied from 55 to $70 \%$. Form stability of the bread ranged from 0.32 to 0.5 . The results of the study showed that in terms of organoleptic and physicochemical indicators, bread samples made from first grade wheat flour without yeast and using whey are much inferior to the quality of the control sample. At the same time, bread samples prepared with starter and starter with whey are almost similar to the control sample.

3 . The results of a study of no yeast bread made from first grade wheat flour showed that in bread made with starter with the addition of whey and ion-ozonized water, the content of protein and fat increased. Protein increased from 0.7 to $1.2 \%$ and fat increased to $3.59 \%$. The amount of yeast significantly decreased in all studied samples, especially in bread made with the addition of whey and ion-ozonized water, as well as made with starter and with the addition of ion-ozonized water - up to $2 \mathrm{CFU} / \mathrm{g}$. As a result, it was found that churning for 3-5 minutes at a kneading body rotation frequency of $4-5 \mathrm{~s}^{-1}$ would be the optimal mode for obtaining a no yeast dough. This mode is intended for preparing dough from first grade flour with starter with the addition of whey and ion-ozonized water.

\section{Acknowledgements}

The work was carried out within the framework of targeted financing of the Ministry of Agriculture of the Republic of Kazakhstan BR10764977 "Development of modern technologies for the production of dietary supplements, enzymes, starters, starch, oils, etc. in order to ensure the development of the food industry" under project No. 1-2021 "Development of flour products with accelerated production cycle based on finely dispersed whole-ground flour obtained by deep processing of grain".

In conclusion, we would like to express our sincere gratitude to all participants in this scientific project for their help and assistance in conducting experimental research. We also express our deep gratitude to the management and scientists of the Almaty Technological University for their help and support.

\section{References}

1. De Bellis, P., Rizzello, C., Sisto, A., Valerio, F., Lonigro, S., Conte, A. et. al. (2019). Use of a Selected Leuconostoc Citreum Strain as a Starter for Making a "Yeast-Free" Bread. Foods, 8 (2), 70. doi: https://doi.org/10.3390/foods8020070

2. Ruttarattanamongkol, K., Wagner, M. E., Rizvi, S. S. H. (2011). Properties of yeast free bread produced by supercritical fluid extrusion (SCFX) and vacuum baking. Innovative Food Science \& Emerging Technologies, 12 (4), 542-550. doi: https://doi.org/ 10.1016/j.ifset.2011.07.006

3. Musatti, A., Mapelli, C., Foschino, R., Picozzi, C., Rollini, M. (2016). Unconventional bacterial association for dough leavening. International Journal of Food Microbiology, 237, 28-34. doi: https://doi.org/10.1016/j.ijfoodmicro.2016.08.011

4. Kapcsándi, V., Hanczné Lakatos, E., Sik, B., Linka, L. Á., Székelyhidi, R. (2021). Antioxidant and polyphenol content of different Vitis vinifera seed cultivars and two facilities of production of a functional bakery product. Chemical Papers, 75 (11), 5711-5717. doi: https://doi.org/10.1007/s11696-021-01754-0

5. Magomedov, G. O., Shevyakova, T. A., Chernysheva, Yu. A., Mazina, E. A. (2013). Poluchenie sbivnyh biskvitov putem mehanicheskogo razryhleniya. Mezhdunarodnaya nauchno-tehnicheskaya konferenciya (zaochnaya) «Innovacionnye tehnologii v pischevoy promyshlennosti: nauka, obrazovanie i proizvodstvo»: sbornik materialov. Voronezh: VGUIT, 355. Available at: https:// www.elibrary.ru/item.asp?id=22716962\&pff=1

6. Popadynets, N., Shults, S., Barna, M. (2017). Differences in consumer buying behaviour in consumer markets of the EU member states and Ukraine. Economic Annals-XXI, 166 (7-8), 26-30. doi: https://doi.org/10.21003/ea.v166-05

7. Sun, Y., Wang, Q., Jin, H., Li, Z., Sheng, L. (2021). Impact of ozone-induced oxidation on the textural, moisture, micro-rheology and structural properties of egg yolk gels. Food Chemistry, 361, 130075. doi: https://doi.org/10.1016/j.foodchem.2021.130075

8. Li, M., Peng, J., Zhu, K.-X., Guo, X.-N., Zhang, M., Peng, W., Zhou, H.-M. (2013). Delineating the microbial and physical-chemical changes during storage of ozone treated wheat flour. Innovative Food Science \& Emerging Technologies, 20, 223-229. doi: https:// doi.org/10.1016/j.ifset.2013.06.004

9. Maemerov, M. M. (2004). Povyshenie roli ozona, kak ekologicheski chistogo metoda obrabotki rastitel'nogo syr'ya. «Strategiya razvitiya pischevoy i legkoy promyshlennosti» materialy konf. Almaty, 59-60.

10. Maemerov, M. M., Iztaev, A. I., Kulazhanov, T. K., Iskakova, G. K. (2011). Nauchnye osnovy ionoozonnoy tehnologii obrabotki zerna i produktov ego pererabotki. Almaty, 246.

11. Puchkova, L. I. (2004). Laboratorniy praktikum po tehnologii hlebopekarskogo proizvodstva. Sankt-Peterburg: GIORD, 264.

12. Iztayev, A., Baibatyrov, T., Mukasheva, T., Muldabekova, B., Yakiyayeva, M. (2020). Experimental studies of the baisheshek barley grain processed by the ion-ozone mixture. Periódico Tchê Química, 17 (35), 239-258. doi: https://doi.org/10.52571/ptq.v17. n35.2020.22_iztayev_pgs_239_258.pdf

13. Ursunbayeva, S. A., Iztayev, R., Gomedov, R., Yakiyayeva, A., Uldabekova, B. Z. (2019). Study of the quality of low-class wheat and bread obtained by the accelerated test method. Periódico Tchê Química, 16 (33), 809-822. doi: https://doi.org/10.52571/ ptq.v16.n33.2019.824_periodico33_pgs_809_822.pdf

14. Zhakatayeva, A., Iztayev, A., Muldabekova, B., Yakiyayeva, M., Hrivna, L. (2020). Scientific security assessment of safety risk of raw sugar products. Periódico Tchê Química, 17 (34), 352-368. doi: https://doi.org/10.52571/ptq.v17.n34.2020.369_p34_pgs_352_368.pdf

15. Iztayev, A., Kulazhanov, T. K., Yakiyayeva, M. A., Zhakatayeva, A. N., Baibatyrov, T. A. (2021). Method for the safe storage of sugar beets using an ion-ozone mixture. Acta Scientiarum Polonorum Technologia Alimentaria, 20 (1), 25-35. doi: https://doi.org/10.17306/j.afs.0865 